\title{
Pedagogical Factors Influencing Training of E-Commerce Entrepreneurs: The Malaysian Case
}

\author{
Noornasirah Nasri, Yulita Hanum P Iskandar \\ Graduate School of Business, Universiti Sains Malaysia, 11800 USM, Penang, Malaysia
}

\begin{abstract}
In Malaysia, many training centres offer e-commerce programmes. However, the quality of their programmes has been a critical issue. Hence, this study aims to investigate pedagogical factors that contribute to effective training of e-commerce entrepreneurs in Malaysia. Data was collected from 200 e-commerce entrepreneurs who attended ecommerce training sessions. The results showed that ecommerce entrepreneurs in Malaysia lack the ability to identify information and understand e-commerce and web system concepts. An analysis reveals that training in this area is not provided. However, other factors (activity and process) have a significant impact on training. This shows that e-commerce entrepreneurs in Malaysia are more likely to continue demonstrating what they know and they are also seen as good information explorers. This paper contributes to pedagogical training by providing useful insights into the factors that influence effective learning by ecommerce entrepreneurs.
\end{abstract}

Keywords - e-commerce entrepreneurs, Training, pedagogy, instructional design.

\section{Introduction}

E-commerce entrepreneurs play a major role as drivers of modern economic development [1].

DOI: 10.18421/TEM103-34

https://doi.org/10.18421/TEM103-34

Corresponding author: Yulita Hanum P Iskandar, Graduate School of Business, Universiti Sains Malaysia, 11800 USM, Penang, Malaysia.

Email:yulita@usm.my

Received: 24 January 2021.

Revised: 19 July 2021.

Accepted: 28 July 2021.

Published: 27 August 2021.

(cc) BY-NC-ND(C) 2021 Noornasirah Nasri \& Yulita Hanum P Iskandar; published by UIKTEN. This work is licensed under the Creative Commons AttributionNonCommercial-NoDerivs 4.0 License.

The article is published with Open Access at www.temjournal.com
The development of training programs for ecommerce entrepreneurs is considered an important component of the "digital entrepreneurial revolution" in recent years [2]. Technically, training should provide relevant, timely information, and improve skills [3], yet studies have found that many ecommerce entrepreneurs face difficulties in applying their understanding although many have undergone training [4]. In Malaysia, the rapid growth of technology in recent years has seen a similar growth trend in entrepreneurial education and training [5] (see table 1).

Table 1. Entrepreneurial Education and Training

\begin{tabular}{|c|c|c|c|c|c|}
\hline Year/Country & $\mathbf{2 0 1 1}$ & $\mathbf{2 0 1 2}$ & $\mathbf{2 0 1 3}$ & $\mathbf{2 0 1 4}$ & $\mathbf{2 0 1 5}$ \\
\hline Malaysia & $2.73 \%$ & $2.94 \%$ & $3.03 \%$ & $3.12 \%$ & $5.15 \%$ \\
\hline
\end{tabular}

The Malaysian government has introduced various education and training initiatives to promote ecommerce among entrepreneurs. Despite that, only $23.3 \%$ of e-commerce entrepreneurs attended formal training programmes [6]. $70 \%$ of Malaysian entrepreneurs still do not have a formal business website [7]. The Global Entrepreneurship Monitor (GEM) had also reported a gradual decrease in the number of Malaysian entrepreneurs since 2012 [8].

The quality and relevance of training programmes are challenges faced by the government and the agencies involved [4], [9]. Consequently, the literature on digital entrepreneurship should include training evaluation and methods that fit the current technology business environment [10].

Inconsistent training delivery can result in learner dissatisfaction, a decrease in knowledge and skill gaps, and untransferable cognitive skills to real tasks [11], [12]. As reported by previous studies, although entrepreneurs are computer literate, they are not adept at digitalizing their businesses to increase profit and productivity. Hence, the level of ecommerce usage is still limited [13]. These factors contribute to a lack of comprehension and failure of entrepreneurs to adopt the latest business technologies [4]. Thus, entrepreneurship training is 
best developed through a modern pedagogical approach such as a delivery method.

Data from several studies on Malaysian entrepreneurial training centres have identified that less than $20 \%$ of pedagogical factors have been provided by trained trainers/training organizers [4], [14]. Furthermore, given that e-commerce is still new in Malaysia, entrepreneurs need to face business uncertainties such as limited knowledge because their knowledge is closely related to cognitive development [4], [15]. Several studies on entrepreneurship have revealed that most ecommerce entrepreneurs in developing countries (including Malaysia) are still taught to use traditional methods rather than the modern ones [16], [17]. Good training depends on good instructional design [18], [19]. However, the instructions provided rarely accommodate different levels of skills [4], [19]. Hence, this causes failure for some Malaysian ecommerce entrepreneurs to digest information given [4], [20].

Untapped potential and capabilities of entrepreneurs cannot be developed with inefficient and inappropriate instruction [18]. These involve pedagogical factors on training that affect their cognitive building and learning mastery [21]. Nevertheless, little emphasis has been given to pedagogical factors [19]. Such inadequate understanding failure among entrepreneurs to apply their knowledge. Thus, they become frustrated and disengaged with this type of learning, and in turn, further demonstrating the complex and hard to interpret issue of training design [19], [22]. This leads to uninteresting learning environments [9], [23]. Thus, this study aims to investigate the pedagogical factors that are influencing training among e-commerce entrepreneurs.

\section{Literature Review and Hypothesis Development}

\subsection{Theoretical Foundation}

Instructional transaction theory (ITT) [22] is a set of components consisting of all of the learning interactions necessary for a learner to acquire a certain kind of knowledge or skill (learning goal) through a computer program. ITT introduced the concept of a learning hierarchy with three sets of transactions representing specific instructional strategies for the learner.

The suitability of the ITT model for studying ecommerce entrepreneurs training is demonstrated in [22] study, where the training based on new pedagogy aligned with the ITT model is examined based on the three factors of pedagogy approaches. The results indicated that the ITT model could fully explain the type of pedagogy in instructional technology. Consequently, this shows that the ITT model is well suited to study training among ecommerce entrepreneurs.

\subsection{Pedagogical Factors}

The ITT shows the pedagogical factors influencing training through instructional transaction elements, namely entity, activity, and process [22]. These factors involve a learning hierarchy that comes as a set of specified intellectual capabilities that an ordered relationship has with each other. According to [22], effective instruction is essential to help an individual learn effectively. Hence, the pedagogical agents can activate the instruction through active participation of the learners in initiating, comprehending, motivating the thinking skills, and reacting to the learning activity [4].

\subsection{Pedagogical Factors of Entity}

Entity factor is a significant determinant of the training environment among e-commerce entrepreneurs [19], [24]. Entity factor is defined as a cognitive "warming-up" where learners activate relevant cognitive structures by being directed to identify the knowledge components [19], [25]. Past research has found entity factors to be positively related to e-commerce entrepreneur training programs [17], [21]. Further, the learning technology literature provides significant evidence of a direct relationship between an entity and a smart learning environment among entrepreneurs [1]. In the context of entrepreneurs, the concept of knowledge identification is defined as the first step to develop plans for acquiring, developing, and reviewing knowledge continuously that can help entrepreneurs to accomplish their tasks better or improve their performance [26]. Therefore, understanding something new is significant as a starting point for mastering knowledge or skills. Given this, the hypothesis is:

H1a: The pedagogical factors of entity influence training among e-commerce entrepreneurs

\subsection{Pedagogical Factors of Activity}

Activity is an important pedagogical factor influencing training, especially in the context of entrepreneurship [22], [23]. The activity factor is defined to demonstrate what learners already know when they know some of the material to be taught [22]. The activation procedure is to develop the knowledge acquired by the learner. Based on this suggestion [22] conducted a research and found that the activity factor is significantly and positively 
related to training entrepreneurs. Empirical studies showed that $80 \%$ of e-commerce entrepreneurs gained benefits from a demonstration when learning related technology (smart Training) [13]. The theorists concurred that if demonstrations are inconsistent with the training goals, then the training will be ineffective [19], [22]. Further, the scholars suggested that the pedagogy should use examples to illustrate the information, and they also emphasized demonstration in addition to the presentation of information [22], [27]. This leads to the second hypothesis:

H1b: The pedagogical factors of activity influence training among e-commerce entrepreneurs

\subsection{Pedagogical Factors of the Process}

Scholars recommended that the pedagogy should test learners to ensure they have learned the new lesson, and this procedure is called the process factor [16], [28]. The purpose is to help the learner to interpret the knowledge learned [19]. The process factor involves the integrative goal of discovering requires problem-solving in which the learner discovers in a cognitive perception, as a new process [17], [19]. [22] found the process factor to be one of the best predictors of training among entrepreneurs. If the process factor is inconsistent with the learning goals of the instruction, then it will be ineffective training [3], [23]. Conversely, when the process factor is consistent, entrepreneurs are capable of interpreting the problem and coming up with the potential solution [19], [22]. The goal of the learner in this stage is to interpret and solve the problem [19], [22]. This may potentially improve the interpretation ability of e-commerce entrepreneurs during Training. Therefore, it is expected that the process factor will be positively related to training. Given this, the next proposed hypothesis is:

H1c: The pedagogical factors of process influence training among e-commerce entrepreneurs

\section{Research Methodology}

\subsection{Measure of Constructs}

The pedagogical factors of entity, activity, and process were measured by adapting from the items developed by [22].This study measures e-commerce entrepreneurs as learners who attend training nine items developed by [29]. Subsequently, the variable was measured based on a 5-point Likert scale ranging from (1) "strongly disagree" to (5) "strongly agree."
This study was conducted with the use of back translation (English and Malay) because English is not the mother-tongue of the target sample in Malaysia. Thus, it was necessary to translate the questionnaire into Malay to ensure the success of the survey. The questionnaire was first translated into Malay by a certified bilingual translator and then translated back into the English language by another certified translator without referring to the original questionnaire. In this study, all of the questionnaires were first written in English and subsequently translated into Malay. Furthermore, both versions of the questionnaire were also checked for grammar and vocabulary by a certified English-Malay translator.

\subsection{Sample}

From the total number of registered entrepreneurs in Table 2, only 47,556 registered entrepreneurs are involved with e-commerce. However, it is not a fixed statistic because the data from the Registrar of Companies (ROC/SSM) is constantly updated. Hence, it is impossible to study the whole population due to limitations of resources and time.

Table 2. Entrepreneurs Statistic in Malaysia

\begin{tabular}{|l|c|c|}
\hline \multicolumn{1}{|c|}{ Entrepreneur } & Total & \\
\hline Registered Business & 920,624 & \\
\hline Registered Online Entrepreneur & 47,556 & \\
\hline
\end{tabular}

The unit of analysis in this study includes entrepreneurs in Malaysian training centres who have employed e-commerce platforms in their businesses and attended e-commerce related training. The respondents of this study are (1) entrepreneurs who have actively attended training on e-commerce in Malaysian public-private training centres and (2) entrepreneurs who are struggling to tap into the full potential of e-commerce in this business journey. Based on the data provided by ROC and the Department of Statistics Malaysia, there has been ecommerce training centres in Malaysia since 2016 (see Figure 1.). However, due to the ever-changing population size, it has become challenging for the researcher to obtain the list of all the training centres in Malaysia. Thus, the study selected only 5 (Selangor, Kuala Lumpur, Johor, Pulau Pinang, and Melaka) out of 16 states in Malaysia based on the percentage of registered online entrepreneurs, which constitutes more than 5\%. 


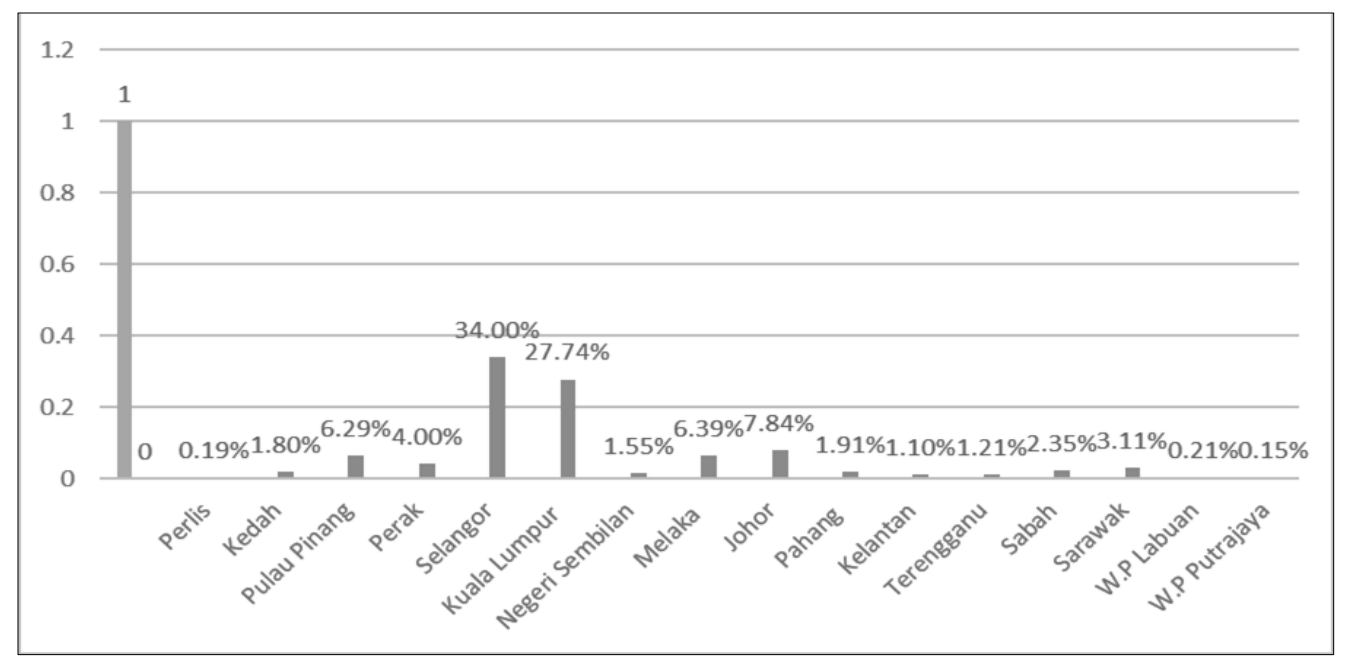

Figure 1. Registered Online Entrepreneur in Malaysia

\subsection{Data Collection}

Initially, formal e-mails were written to the selected public-private training centres, enclosed with the official letter and the sample of questionnaires to be forwarded to their respective officers or program coordinators. Besides that, some were also contacted by telephone calls before the official letter was written.

Upon receiving confirmation from the training centres, the questionnaires were then distributed and self-delivered by the researcher to the selected training centres. These training centres are the result of collaborations between government agencies and a private sector companies such as the Malaysia Internet

\section{Results}

However, there were several cases of confidentiality issues in which some training coordinators asked the researcher to post the online survey on their forums.

\subsection{Descriptive Statistic of Respondents}

Table 3 presents a demographic profile of respondents. The sample consists of a total of 200 respondents. Among these respondents, the majority of them (74\%) were youths below 40 years old. $41 \%$ of the respondents' were between 21 to 30 years old, $33 \%$ were between 31 to 40 years old. More than half of the respondents are female $(67.5 \%)$, and the remaining (32.5\%) are male. The majority of the respondents are Malay (83.5\%), followed by Chinese (8.5\%), Indian (7\%) and other races (1\%). 56.5\% of respondents have a diploma (29\%) and a bachelor's degree $(27.5 \%)$. The other $43.5 \%$ of respondents have a certificate (19\%), 16\% finished high school, and
Entrepreneur Association (MIEA), the Selangor Information Technology and E-Commerce Council (SITEC Academy), the Malaysia External Trade Development Corporation (MATRADE), the Malaysia Young Entrepreneur Association (PUMM), the SME Corporation Malaysia (SME Corp), and the Malaysia Digital Economy Corporation (MDEC).

\subsection{Analysis}

This research adopted PLS-SEM as the statistical procedure to evaluate the research model, by which the estimation and interpretation of the PLS-SEM model include a two-step process that encompasses a separate assessment of the outer model (measurement model) and the inner model (structural model) [30].

With the permission of the website administrators, the URL for the online questionnaire was posted on the discussion boards to collect data.

only $8.5 \%$ have post-graduate degrees. $35.5 \%$ of the respondents had intermediate level e-commerce experience, followed by beginner's level of experience $(26 \%)$, expert $(24.5 \%)$, and professional $(14 \%)$. The majority of the respondents have less than six years of experience in e-commerce $(78.5 \%)$, and only $21.5 \%$ of them have more than six years' experience in e-commerce. The analysis showed close results between respondents who attended training after they establish an online business (66\%) and the respondents who attended training before they establish their online business (64\%). Next, 58\% of the respondents agreed that e-commerce training is needed, with $58 \%$ of them involved in e-commerce training more than twice. Finally, most of the respondents personally gained their competencies (74\%) after they attended a series of training programs. 
Table 3. Descriptive Statistics of Respondents

\begin{tabular}{|c|c|c|}
\hline Demographic & $\begin{array}{l}\text { Frequency } \\
\qquad(n=200)\end{array}$ & $\begin{array}{c}\text { Percentage } \\
(\%)\end{array}$ \\
\hline \multicolumn{3}{|c|}{ Age } \\
\hline $\begin{array}{c}20 \text { and below } \\
21-30 \\
31-40 \\
41-50 \\
61 \text { and above }\end{array}$ & $\begin{array}{c}14 \\
82 \\
66 \\
31 \\
7\end{array}$ & $\begin{array}{c}7.0 \% \\
41 . \% \\
33.0 \% \\
15.5 \% \\
3.5 \%\end{array}$ \\
\hline \multicolumn{3}{|c|}{ Gender } \\
\hline $\begin{array}{l}\text { Male } \\
\text { Female }\end{array}$ & $\begin{array}{c}65 \\
135\end{array}$ & $\begin{array}{l}32.5 \% \\
67.5 \%\end{array}$ \\
\hline \multicolumn{3}{|c|}{ Race } \\
\hline $\begin{array}{l}\text { Malay } \\
\text { China } \\
\text { India } \\
\text { Others }\end{array}$ & $\begin{array}{c}167 \\
17 \\
14 \\
2\end{array}$ & $\begin{array}{l}83.5 \% \\
8.5 \% \\
7.0 \% \\
1.0 \%\end{array}$ \\
\hline \multicolumn{3}{|c|}{ Education } \\
\hline $\begin{array}{c}\text { High School } \\
\text { Certificate } \\
\text { Diploma } \\
\text { Bachelor Degree } \\
\text { Post-Graduate }\end{array}$ & $\begin{array}{l}32 \\
38 \\
58 \\
55 \\
17\end{array}$ & $\begin{array}{c}16 \% \\
19 \% \\
29.0 \% \\
27.5 \% \\
8.5 \% \\
\end{array}$ \\
\hline \multicolumn{3}{|c|}{ Experience } \\
\hline $\begin{array}{c}\text { Beginner } \\
\text { Intermediate } \\
\text { Expert } \\
\text { Professional }\end{array}$ & $\begin{array}{l}52 \\
71 \\
49 \\
28\end{array}$ & $\begin{array}{l}26 \% \\
35.5 \% \\
24.5 \% \\
14.0 \%\end{array}$ \\
\hline \multicolumn{3}{|c|}{ How Long Involve in E-commerce Business } \\
\hline $\begin{array}{c}2 \text { years or less } \\
3-5 \text { years } \\
6 \text { years or more }\end{array}$ & $\begin{array}{l}78 \\
79 \\
43\end{array}$ & $\begin{array}{c}39 \% \\
39.5 \% \\
21.5 \% \\
\end{array}$ \\
\hline \multicolumn{3}{|c|}{ Formal Training Before } \\
\hline $\begin{array}{l}\text { Yes } \\
\text { No }\end{array}$ & $\begin{array}{c}128 \\
72\end{array}$ & $\begin{array}{l}64.0 \% \\
36.0 \%\end{array}$ \\
\hline \multicolumn{3}{|c|}{ Formal Training After } \\
\hline $\begin{array}{l}\text { Yes } \\
\text { No }\end{array}$ & $\begin{array}{c}132 \\
68\end{array}$ & $\begin{array}{l}66 \% \\
34 \%\end{array}$ \\
\hline \multicolumn{3}{|c|}{ E-commerce Training is Needed } \\
\hline $\begin{array}{c}\text { Yes } \\
\text { No } \\
\text { Not sure } \\
\end{array}$ & $\begin{array}{c}116 \\
51 \\
33 \\
\end{array}$ & $\begin{array}{l}58.0 \% \\
25.5 \% \\
16.5 \% \\
\end{array}$ \\
\hline \multicolumn{3}{|c|}{ Frequently Involve in E-commerce Training } \\
\hline $\begin{array}{l}\text { Once } \\
\text { More than twice }\end{array}$ & $\begin{array}{c}84 \\
116\end{array}$ & $\begin{array}{l}42 \% \\
58 \%\end{array}$ \\
\hline Compe & entage & \\
\hline
\end{tabular}

\begin{tabular}{|c|c|c|}
\hline Less than $25 \%$ and up to $50 \%$ & 0 & $0 \%$ \\
$50 \%$ and up to $75 \%$ & 52 & $26 \%$ \\
More than $75 \%$ or fully & 148 & $74 \%$ \\
competent & & \\
\hline
\end{tabular}

\subsection{Common Method Bias}

The research performed Harman's single factor test which revealed that the first factor accounted for $47.73 \%$ of the variance, less than the threshold level of $50 \%$ of total variance explained. This, in turn, demonstrates that common method bias is not a major concern in the data.

\subsection{Measurement Model Results}

PLS-SEM analysis is used to analyse the measurement (outer model) to discover how well the indicators (through specific questions) load on the constructs before proceeding to test the structural (inner model) [30], [31]. Table 4 shows all indicator loadings higher than 0.70 . The evaluation of the measurement model in this research was guided by the confirmatory factor analysis (CFA). CFA was tested to measure the convergent and discriminant validity of constructs in the framework model. Convergent validity was examined to investigate which two different indicators measuring the same construct is highly correlated. 
Table 4. Measurement Assessment: Loadings, CR and AVE

\begin{tabular}{|c|c|c|c|c|}
\hline Variable & Indicator & Loadings & $\mathbf{C R}$ & AVE \\
\hline \multirow{3}{*}{$\begin{array}{l}\text { Pedagogical } \\
\text { factors of } \\
\text { activity }\end{array}$} & This Training encourages me to take action immediately. & 0.825 & \multirow{3}{*}{0.893} & \multirow{3}{*}{0.736} \\
\hline & $\begin{array}{l}\text { I pay attention to Training if the topics taught are similar to the } \\
\text { problems I am facing in my online business. }\end{array}$ & 0.834 & & \\
\hline & $\begin{array}{l}\begin{array}{l}\text { I can enrich new knowledge as my previous knowledge gets } \\
\text { developed. }\end{array} \\
\end{array}$ & 0.911 & & \\
\hline \multirow{5}{*}{$\begin{array}{l}\text { Pedagogical } \\
\text { factors of } \\
\text { entity }\end{array}$} & $\begin{array}{l}\text { The focus of the Training is more on process than the knowledge of } \\
\text { performing tasks. }\end{array}$ & 0.758 & \multirow{5}{*}{0.902} & \multirow{5}{*}{0.65} \\
\hline & $\begin{array}{l}\text { Using the principles of media elements (slides/diagram/video) as a } \\
\text { guide is helpful. }\end{array}$ & 0.73 & & \\
\hline & Critical tasks (in online businesses) need more Training. & 0.815 & & \\
\hline & $\begin{array}{l}\text { Showing (demonstration) what needs to be learned is important than } \\
\text { telling what needs to be learned. }\end{array}$ & 0.91 & & \\
\hline & $\begin{array}{l}\text { The design of the training activities is equal to the real situation in my } \\
\text { online business. }\end{array}$ & 0.807 & & \\
\hline \multirow{4}{*}{$\begin{array}{l}\text { Pedagogical } \\
\text { factors of the } \\
\text { process }\end{array}$} & $\begin{array}{l}\text { Accurate learning content in Training will produce a fun learning } \\
\text { experience. }\end{array}$ & 0.846 & \multirow{4}{*}{0.853} & \multirow{4}{*}{0.595} \\
\hline & The training component represents the training structure. & 0.85 & & \\
\hline & $\begin{array}{l}\text { The use of a different approach for each type of knowledge makes my } \\
\text { understanding easier. }\end{array}$ & 0.663 & & \\
\hline & $\begin{array}{l}\text { New knowledge is presented in a way that is easily understood in } \\
\text { Training. }\end{array}$ & 0.707 & & \\
\hline \multirow{9}{*}{ Training } & The instructors teach effectively in this Training. & 0.772 & \multirow{9}{*}{0.942} & \multirow{9}{*}{0.643} \\
\hline & The instructors are very helpful to me. & 0.79 & & \\
\hline & I know how my online business should grow through this Training. & 0.792 & & \\
\hline & The training material is related to my online business. & 0.77 & & \\
\hline & The training topic is related to my online business. & 0.78 & & \\
\hline & $\begin{array}{l}\text { Previously, I believed that my online business needs to be upgraded } \\
\text { based on topics in the training programme. }\end{array}$ & 0.883 & & \\
\hline & $\begin{array}{l}\text { I can change for the sake of the future development of my online } \\
\text { business as a result of this Training. }\end{array}$ & 0.875 & & \\
\hline & $\begin{array}{l}\text { I can make new plans for the future development of my online } \\
\text { business as a result of this Training. }\end{array}$ & 0.713 & & \\
\hline & The instructors teach effectively in this Training. & 0.828 & & \\
\hline
\end{tabular}

\subsection{Assessment of the Structural Model}

HTMT is the latest addition of discriminant validity. HTMT is based on the ratio of the within construct correlation to the between construct correlation and can assess discriminant validity more reliably. There are rules of thumb of HTMT usage. 
TEM Journal. Volume 10, Issue 3, Pages 1274-1284, ISSN 2217-8309, DOI: 10.18421/TEM103-34, August 2021.

Firstly, HTMT values should be lower than 0.85. and 0.90 . Next, the confidence interval for HTMT values for the hypothesis containing the value 1 , a lack of discriminant validity can be detected.

Table 5 shows the HTMT values. As a result, all values in the table are below the .90 , demonstrating that discriminant validity has been established.

Table 5 shows the HTMT values. As a result, all values in the table are below the .90 , demonstrating that discriminant validity has been established.

Table 5. Discriminant Validity HTMT

\begin{tabular}{|l|c|c|c|c|}
\hline & $\begin{array}{c}\text { Pedagogical factors of } \\
\text { activity }\end{array}$ & $\begin{array}{c}\text { Pedagogical factors } \\
\text { of entity }\end{array}$ & $\begin{array}{c}\text { Pedagogical factors of the } \\
\text { process }\end{array}$ & $\begin{array}{c}\text { Traini } \\
\text { ng }\end{array}$ \\
\hline $\begin{array}{l}\text { Pedagogical factors of } \\
\text { activity }\end{array}$ & 0.75 & & & \\
\hline $\begin{array}{l}\text { Pedagogical factors of } \\
\text { entity }\end{array}$ & 0.864 & 0.630 & & \\
\hline $\begin{array}{l}\text { Pedagogical factors of the } \\
\text { process }\end{array}$ & 0.854 & 0.642 & 0.724 \\
\hline Training & & & & \\
\hline
\end{tabular}

The path coefficient between two constructs is assessed to validate the hypotheses, and the structural model is obtained by running the PLS algorithm followed by bootstrapping procedure (with 1000 samples and 200 cases) in SmartPLS (version 3.0).
Table 6. represented the results of the direct effect hypothesized relationships of this research. Based on the findings from the structural model, the hypotheses of entity toward training (H1a) with path coefficient ( $\beta$-value) 0.142 ( $\mathrm{p}$-value $=0.147$ ) and effect size of 0.02 was not supported because of the insignificant $\mathrm{p}$-value $(\mathrm{P}<0.05)$ and small effect size in this study. The other hypotheses, such as activity toward training ( $\mathrm{H} 1 \mathrm{~b})$ with $\beta$-value of 0.551 ( $\mathrm{p}$-value $=\mathrm{p}<0.01)$, the process toward training $(\mathrm{H} 1 \mathrm{c})$ with $\beta$ value of 0.184 ( $\mathrm{p}$-value $=\mathrm{p}<0.01)$ were supported respectively in this study. Therefore, $\mathrm{H} 1 \mathrm{~b}$ and $\mathrm{H} 1 \mathrm{c}$ of this research were supported, whereas H1a was not.

Table 6. Significance of direct effects- Path coefficients $(n=200)$

\begin{tabular}{|c|c|c|c|c|c|c|c|}
\hline Hypothesis & Relationship & $\begin{array}{c}\text { Path } \\
\text { coefficients } \\
(\beta-\text { value })\end{array}$ & $\begin{array}{c}\text { Standard } \\
\text { Error }\end{array}$ & $\begin{array}{c}\mathrm{T} \\
\text { Value }\end{array}$ & $\begin{array}{c}\mathrm{P} \\
\text { Values }\end{array}$ & $\begin{array}{c}\text { Effect } \\
\text { Size } \\
\left(\mathrm{f}^{2}\right)\end{array}$ & $\begin{array}{c}\text { Result } \\
\text { Supported }\end{array}$ \\
\hline H1a & $\begin{array}{c}\text { Pedagogical factors of } \\
\text { entity -> Training }\end{array}$ & 0.142 & 0.098 & 1.451 & 0.147 & 0.02 & No \\
\hline H1b & $\begin{array}{c}\text { Pedagogical factors of } \\
\text { activity -> Training }\end{array}$ & 0.551 & 0.065 & 8.471 & 0.00 & 0.32 & Yes \\
\hline H1c & $\begin{array}{c}\text { Pedagogical factors of } \\
\text { process -> Training }\end{array}$ & 0.184 & 0.077 & 2.385 & 0.017 & 0.04 & Yes \\
\hline
\end{tabular}




\section{Discussion}

\subsection{Pedagogical Factors of Entity}

The relationship between the pedagogical factor of entity and training has been examined. Contrary to the researcher's expectation, this research did not find any significant difference between the pedagogical entity and training. Thus, the result was in contrast with mainstream results by [25], [28]. It was found that the potential benefits resulting from the entity factor are important in this study, even though previous researchers [22], [28] agreed that the expected benefits resulting from the use of entity represent a knowledge identification that motivates ecommerce entrepreneurs to be able to identify and denote the knowledge components (symbols, definition, names, or things) as a cognitive 'heater' for the beginning of the learning process as well as helping them understand the procedural knowledge before performing the procedure that would increase their digital business performance and efficiency.

Despite the insignificant relationship of the entity factor on e-commerce training, this does not convey that training programmes have a low level of benefits. Instead, it could be argued that e-commerce entrepreneurs in Malaysia understand the entity factor involved in these programmes. However, their knowledge might be inadequate. One possible reason is that e-commerce is a new business area for entrepreneurs in Malaysia with complex knowledge and skill requirements. Besides that, it is also possible that the potential advantages of attending training programmes are still not clear to them, and their existing knowledge has not been as satisfactory in terms of digital business requirements. It can be seen that the percentage of e-commerce entrepreneurs who attend training in Malaysia is still in the range of low to moderate [32]. Thus, it can also be argued that generally, there is still a lack of awareness related to pedagogy among training centres. As explained by [4], [17], training centres in Malaysia are still weak at

establishing the knowledge of e-commerce concept among e-commerce entrepreneurs' due to the lack of pedagogical factors $(20 \%)$.

Given such circumstances, more promotional efforts are required to increase knowledge and awareness in training centres of the potential benefits and advantages of e-commerce related training programs to increase their ability to use such systems in their businesses.

Based on the current findings, e-commerce entrepreneurs in Malaysia are more inclined towards the process of performing tasks than the knowledge of performing tasks. According to [13], weaknesses were found in the areas of knowledge and technology skills received during training. Consequently, this has caused cognition distortions in terms of knowledge identification among e-commerce entrepreneurs which leads to problems in the real-life e-commerce ecosystem. Thus, this explains the reason for the irrelevant influence of the entity factor on entrepreneurial training programmes. Besides, high dependence on the trainers also contributes to failure to identify the knowledge components delivered. Hence, to increase e-commerce entrepreneurs' perceptions of the advantages of smart pedagogy, training organizers and the government need to provide relevant training programs, which in turn cultivate smart learning environments.

Most studies on pedagogical knowledge transfer of entity have been conducted outside Malaysia, such as by [20], [25]. However, in the Malaysian context as a developing country, the entity factor does not emerge as a significant contributor to the development of training even though this factor has been argued to be important in developing a positive knowledge strategy. This factor, surprisingly, did not significantly impact the development of pedagogical entity among local e-commerce entrepreneurs in Malaysian training centres. Although the entity factor was found to not have significant impact on ecommerce training, some e-commerce entrepreneurs to a certain extent have gained experience from the previous training they attended. In summary, the above discussion has explained the reasons behind the statistically insignificant relationship between the entity factor and Training among e-commerce entrepreneurs in Malaysia.

\subsection{Pedagogical Factors of Activity}

The relationship between the pedagogical factor of activity and training has been examined. Based on the results of this study, it was found that the activity factor is positively related to training and this is similar to the studies on entrepreneur instructional technology by [22], [33]. Their findings indicated that the activity factor is significantly related to instructional technology in cognitive interaction among entrepreneurs. In this context, the activity factor that influences training refers to the individual cognitive on demonstration of information as a response to the intellectual skills that are aimed at the discovery and exploratory learning. Briefly, it should be noted that the activity factor is the degree of entrepreneurs' ability to develop knowledge that involves a decision-making procedure. The activity factor is one of the sets of components comprising of the interactions necessary for e-commerce entrepreneurs to acquire a particular kind of knowledge or skill, such as a computer program that encapsulates the conditions for learning a given type 
of knowledge. Correspondingly, this result is supported by prior findings related to the activity factor of pedagogy, which suggests that entrepreneurs' cognitive has a positive influence on ecommerce in Malaysia.

In Malaysia, e-commerce development is still at a moderate level. Although the entrepreneurs have good ICT skills and internet accessibility, in reality, they are still struggling to manage the e-commerce gap [13]. Hence, the positive impact of the activity factor on training shows that the cognitive skills of Malaysian e-commerce entrepreneurs lead them only to a theoretical understanding of their digital business.

Also, training centres still provide a traditional training model, which has become the main barrier to the development and implementation of smart training programs [4], [9]. Therefore, the role of the pedagogical factor of activity is highlighted to facilitate the adoption of a smart training environment in training centres. Further, it is believed that the level of pedagogy is more dependent on the activity factor to enhance the training consistency. The reason is that when the e-commerce entrepreneurs attend trainings, their commitment to the activity factor shows how fast the pedagogy leads to achieving the learning goals. Hence, this research provides justifications for why the pedagogical factor of activity towards training has a significant impact on the development of e-commerce entrepreneurs in Malaysia.

\subsection{Pedagogical Factors of the Process}

The pedagogical factor of the process also has a significant impact on training, and this is in line with various past studies that found a significant link between process and training [19]. In this study, the pedagogical process refers to the situation that allows entrepreneurs to be exposed to new knowledge or information. This result is consistent with most of the prior literature on instructional learning systems, which suggested that learning is promoted when learners are required to use their new knowledge or skills to solve problems [20], [34].

The mean scores indicate that e-commerce entrepreneurs tend to learn effectively when the learning environment is fun and the delivery is interesting. In line with previous studies, curiosity and interest will encourage learners to participate in the learning activity to produce a positive cognitive in terms of problem-solving if the problems to be solved are interesting, relevant and engaging [25], [35]. As such, the entrepreneurs' curiosity allows them to discover the reason for developing a new strategy. For example, to upgrade the e-commerce system with the latest version or solely for a maintenance procedure. According to [22], making errors is a natural consequence of problem-solving. Hence, it can be said that Malaysian e-commerce entrepreneurs are information settlers as they learn from the errors they make and how they recover from them.

The majority of the training centres in Malaysia are still on an inconsistent training curriculum. Hence, the role of the process factor is crucial in adopting a smart training environment. This is also supported by [2], who found that even though learning situations may be flexible or diverse in the sense that they may be approached by differential learning styles, the interpretation of the learning situation should prescribe the form of the action experienced. Entrepreneurs come from different business backgrounds, learning styles, abilities, and thinking. Thus, they need appropriate training to suit their needs. The significant impact of the process factor on training will assist training organizers, administrators and the government to understand the needs of an effective e-commerce training programme. Drawing from the findings of this study, it can be inferred that the availability of the pedagogical process as the demonstrating part is important for the development of how training Malaysian e-commerce entrepreneurs is conducted.

\section{Theoretical Implications}

A learning environment technology is considered smart if it is effective, efficient, and engaging. Thus, this research has highlighted the importance of pedagogical factors such as entity (identifying), activity (demonstrating), and process (interpreting) in training e-commerce entrepreneurs using a smart learning concept. The results from the findings demonstrated an insignificant effect of the entity factor, which involves the entrepreneurs' identification skills. However, the contribution of the entity factor to entrepreneurs should not be ignored because it constitutes learning and identifying knowledge. For example, the development of intellectual skills drawn from knowing, identifying, and denoting as an entity involves a cognitive domain that the learners need as the start of obtaining new knowledge before they can proceed to the next level of the learning process until they ultimately achieve the learning objective [25]. Therefore, the findings suggest that it is essential for e-commerce entrepreneurs to nurture their knowledge identification and intellectual skills by identifying the knowledge components. 


\section{Practical Implications}

Implementing training for e-commerce entrepreneurs requires the existence of appropriate government policies and support. As such, the government can review the policies and incentives in promoting the growth and development of training programmes involving e-commerce entrepreneurs. As mentioned previously, the government of Malaysia has implemented measures to refine and enhance training programmes for digital entrepreneurs to be relevant in the $5 \mathrm{G}$ era technology in response to the fourth industrial revolution. This advancement in technology requires a rapid response through Information 4.0. Hence, the current pedagogy should be revised to provide effective learning by equipping e-commerce entrepreneurs with the appropriate skills needed so that they can compete in the frequently changing digital market.

The research model will help maximize the potential benefits of Malaysian training centres through an understanding of the pedagogical factors that influence the implementation of training related to e-commerce. Also, this research provides advanced guidance from the training module to learning systems through simulated exercises for e-commerce entrepreneurs; the module is also assumed to be designed to different kinds of knowledge goals through the same strategy of an instructional algorithm. Hence, the government needs to develop a comprehensive training policy that emphasizes the continuous development of a smart training environment that can capture the e-commerce entrepreneurs' human capital, cognition skills, performance, competencies problem-solving, decision-making, and credibility in handling digital businesses.

\section{Conclusion}

As technology develops, many entrepreneurs nowadays look to e-commerce due to its potential to be more profitable, cost-effective, and can penetrate larger markets. This is on the basis that e-commerce integration in business processes is growing. As such, e-commerce is important for the ongoing survival of entrepreneurs since it has risen significantly in recent years. Various business training for the growth of ecommerce ecosystems among entrepreneurs has been initiated by the government in most industries. However, inconsistent and ineffective training content has impeded growth. According to the activation principle, learning is promoted when learners activate relevant cognitive structures as they remember, describe, or demonstrate relevant prior knowledge or experience [25]. Hence, the development of ecommerce entrepreneurs should be done within the modern training environment which demands the formulation of an integrated learning strategy that aligns the learning objectives with the valid pedagogical selection [19]. While learning among entrepreneurs remains rooted in a particular pedagogy, the learning models can be modernised to better improve entrepreneurs.

\section{References}

[1]. Fadzil, A. F. M., Yaacob, M. R., \& Muhayiddin, M. N. (2017). The Roles of Competencies in the New Venture Creation among E-Commerce Entrepreneurs in Malaysia. International of Business and Management Invention, 6(3), 25-31.

[2]. Azim, M. T., \& Al-Kahtani, A. H. (2015). Designing entrepreneurship education and training program: In search of a model. Journal of Economics and Sustainable Development, 6(22), 112-127.

[3]. Al-Akkad, J. A. M. A. L. (2018). Aligning the appeal of entrepreneurs to investors: why is there a need for an optimal entrepreneurship training module in the Kingdom of Saudi Arabia to better engage entrepreneurs with investors (Doctoral dissertation, Durham University).

[4]. Imenda, S. N. (2018). On the Unity of Behaviourism, Cognitivism and Constructivism in Teaching and Learning. International Journal of Educational Sciences, 20(1-3), 86-95.

[5]. Monitor, G. G. E. (2015). Global Entrepreneurship Monitor-Adult Population Survey Measures, 2015.

[6]. Sofian, S. A. B. (2018). Factors impacting the success of Malaysian internet entrepreneurs. Human Sustainability Procedia.

[7]. Madhushree H G and Sunayana N. (2018). Comparative Analysis on Behaviour of Trained and Untrained Entrepreneurs - A Study on Dairy Industry. International Journal of Mechanical Engineering and Technology (IJMET), 9(1), pp. 1005-1009.

[8]. Sipon, M., Pihie, Z. A. L., Rahman, F. A., \& Manaf, U. K. A. (2015). Teacher's entrepreneurial pedagogical content knowledge roles in human resource development. International journal of management and applied research, 2(1), 35-44.

[9]. Pollock, R. V., Jefferson, A., \& Wick, C. W. (2015). The six disciplines of breakthrough learning: How to turn training and development into business results. John Wiley \& Sons.

[10]. Yusoff, M. N. H., Ismail, M., Hassan, H., \& Mamum, A. A. (2019). Entrepreneurship competency enhancement training: a study among the managers of Internet centres. International Journal of Academic Research in Business \& Social Sciences, 9(7), 233245.

[11]. Ismail, A. B. (2017). We are different: a case study of entrepreneurship education in Malaysia (Doctoral dissertation, Queensland University of Technology).

[12]. Yaacob, M. R., Shaupi, N. S. A., \& Shuaib, A. S. M. (2016). Perception towards factors that affect the effectiveness of an entrepreneurship training program. Journal of Entrepreneurship and Business (JEB), 4(1), 50-58. 
[13]. Zulkarnain, E. F., Abdullah, A. N. F. B., \& Ridzuan, A. A. (2019). Tahap Pendigitalan Perniagaan Dalam Kalangan Usahawan PKS MARA di Melaka. Politeknik \& Kolej Komuniti Journal of Life Long Learning, 3(1), 130-140.

[14]. Rahim, H. L., Abdul Kadir, M. A. B., Zainal Abidin, Z., Junid, J., Mohd Kamaruddin, L., Mohd Lajin, N. F., ... \& Ahmad Bakri, A. (2015). Entrepreneurship education in malaysia: a critical review. Journal of Technology Management and Business, 2(2), 1-11.

[15]. Fadzil, A. F. M., PLG, M. R. Y., \& Muhayiddin, M. N. (2018). The relation of entrepreneur cognition and personality: The determinant factors of e-commerce entrepreneurship involvement

Malaysia. International Journal of Asian Social Science, 8(12), 1228-1235.

[16]. Lorenzo, N., \& Gallon, R. (2019). Smart pedagogy for smart learning. In Didactics of smart pedagogy (pp. 41-69). Springer, Cham.

[17]. Samuel, A. B., \& Rahman, M. M. (2018). Innovative teaching methods and entrepreneurship education: A review of literature. Journal of Research in Business, Economics and Management, 10(1), 1807-1813.

[18]. Khalil, M. K., \& Elkhider, I. A. (2016). Applying learning theories and instructional design models for effective instruction. Advances in physiology education, 40(2), 147-156.

[19]. Spector, J. M. (2016, March). Smart learning environments: Concepts and issues. In Society for Information Technology \& teacher education international conference (pp. 2728-2737). Association for the Advancement of Computing in Education (AACE).

[20]. Kousar, M. J. I. N., \& Rahman, F. (2011). Effects of interaction on achievement of distance learners. International Journal of Business and Social Science, 2(12).

[21]. Okeke, C. O., \& Yong, D. G. F. (2016). Assessment of entrepreneurship pedagogy on entrepreneurship knowledge and entrepreneurial human capital asset: A conceptual model. Knowledge Management \& ELearning: An International Journal, 8(2), 243-258.

[22]. Merrill, M. D. (2012). Instructional transaction theory: An instructional design model based on knowledge objects. Instructional Design: International Perspectives: Volume I: Theory, Research, and Models: volume Ii: Solving Instructional Design Problems, 381.
[23]. Moate, R. M., \& Cox, J. A. (2015). Learner-Centered Pedagogy: Considerations for Application in a Didactic Course. Professional Counselor, 5(3), 379389.

[24]. Astleitner, H. (2018). Multidimensional Engagement in Learning--An Integrated Instructional Design Approach. Journal of Instructional Research, 7, 6-32.

[25]. Rosenberg-Kima, R. B. (2012). Effects of taskcentered vs. topic-centered instructional strategy approaches on problem solving-Learning to program in Flash. The Florida State University.

[26]. Townsend, D. M., Hunt, R. A., McMullen, J. S., \& Sarasvathy, S. D. (2018). Uncertainty, knowledge problems, and entrepreneurial action. Academy of Management Annals, 12(2), 659-687.

[27]. Daniela, L., \& Lytras, M. D. (2018). SMART pedagogy:(Re) defining pedagogy. In Learning strategies and constructionism in modern education settings (pp. 1-15). IGI Global.

[28]. Lorange, P., \& Thomas, H. (2016). Pedagogical advances in business models at business schools-in the age of networks. Development, 35(7), 889-900.

[29]. Steele, P. K. (2016). "Effective General Entrepreneurial Learning Programs for SME Development" Capstone Collection. Paper 290.

[30]. Hair Jr, J. F., Hult, G. T. M., Ringle, C. M., \& Sarstedt, M. (2021). A primer on partial least squares structural equation modeling (PLS-SEM). Sage publications.

[31]. Hair Jr, J. F., Sarstedt, M., Hopkins, L., \& Kuppelwieser, V. G. (2014). Partial least squares structural equation modeling (PLS-SEM): An emerging tool in business research. European business review.

[32]. Lim, S. C., Baharudin, A. S., \& Low, R. Q. (2017). Factors influence SMEs in Malaysia to adopt ecommerce: Moderating roles of perceived strategic value. Journal of Engineering and Applied Sciences, 12(6), 1566-1574.

[33]. Ganotakis, P., \& Lindsay, V. (2016). E-commerce adoption within an entrepreneurial context.

[34]. Glover, I., Hepplestone, S., Parkin, H. J., Rodger, H., \& Irwin, B. (2016). Pedagogy first: Realising technology enhanced learning by focusing on teaching practice. British Journal of Educational Technology, 47(5), 993-1002.

[35]. Boula, J., Morgan, K., Morrissey, C., \& Shore, R. (2017). How Do Students Understand New Ideas? In Response to the Deans for Impact Report (DFI). Journal of Applied Educational and Policy Research, 3(1). 